\title{
Recovery of Infectious TMV from a Single Aphid by the Use of Bentonite
}

\author{
Toshimichi YoshIZAKI* \\ 由崎俊道*：ベントナイトの使用による単一フブラムシ中の感染性 TMV の検出
}

\begin{abstract}
The addition of bentonite suspension to inoculum allowed the recovery of infectivity of tobacco mosaic virus (TMV) on Nicotiana glutinosa L. from the homogenates of a single aphid which had been fed on infected plants or purified TMV through a membrane. Infectivity of ribonucleic acid (TMV-RNA) acquired by aphids was not recovered in this manner. Aphids lost infectivity of acquired TMV after 3 or 4 days when they were fed on $15 \%$ sucrose in $0.02 \mathrm{M}$ phosphate buffer through a membrane. A majority of the infectious TMV acquired by aphids was released into honeydew, but not through the stylet into sucrose solution or leaf disks. Since the total amount of infectivity that remained in dead aphids decreased with increasing incubating periods at room temperature, it is considered that a certain quantity of TMV acquired by aphids is inactivated in the insect bodies.
\end{abstract}

(Received April 18, 1980)

\section{Introduction}

There have been several reports regarding aphid transmission of $\mathrm{TMV}^{3,4,7,8)}$, but it is generally believed that this virus is not transmissible by aphids, ${ }^{6,13,19)}$. Several authors $10,11,16,22)$ using electron microscopy have reported that purified TMV or TMV from infected plants is acquired by aphids. It has also been reported that infectious TMV is released into a phosphate buffer solution by aphids which had probed purified TMV through a membrane ${ }^{17)}$, and that the virus in the mid-gut is infectious ${ }^{22)}$. However, there has been no report on quantitative assay of the virus acquired by aphids. The major difficulty for assaying its infectivity is that aphid homogenates strongly inhibit virus infectivity ${ }^{1,12}$. As it is known that bentonite prevents the reaction of ribonuclease ${ }^{2,18)}$ and the effect of inhibitors on TMV and TMV-RNA ${ }^{24)}$, the present study was done to determine whether bentonite could prevent the inhibitory effect of aphid homogenates on TMV. The addition of bentonite to the homogenate from even a single aphid which had been fed on purified TMV or on infected plants was found to remarkably increase the infectivity of TMV.

\section{Materials and Methods}

The green peach aphids, Myzus persicae Sulz. (green clone), was used for the experiments. Turnip (Brassica rapa L.) and the buds from tulip bulbs were used for propagating

* Sapporo College, Hokkaido University of Education, Sapporo, Hokkaido 064, Japan 北海道教育 大学札幌分校生物学教室 
the aphids. All experiments were conducted with apterous aphids. Plants used in these experiments were grown in pots and cultivated in a green house. The ordinary ( $\left.\mathrm{O}_{-}\right)$ or the L-strain ${ }^{15)}$ of TMV was propagated in tobacco plants (N. tabacum L. cv. Samsun), and the $\mathrm{C}-$-strain $^{14)}$ of TMV was propagated in turnip plants. TMV was purified by differential centrifugation ${ }^{20)}$. TMV-RNA was prepared from purified TMV by bentonitephenol method ${ }^{5)}$. The concentration of TMV and TMV-RNA was determined spectrophotometrically ${ }^{21)}$. Two kinds of plastic rings, 2.9 and $1.8 \mathrm{~cm}$ in diameter, and 2.0 and $1.0 \mathrm{~cm}$ in height, respectively, were used as cages for feeding aphids through Parafilm membrane*. The upper end of the ring covered with the Parafilm, which was then sucked slightly by an aspirator on the under side of the ring to make a shallow hollow in the membrane. The test materials were placed into the hollow and covered with another membrane. Volumes of 0.7 and $0.3 \mathrm{ml}$ were used for 2.9 and $1.8 \mathrm{~cm}$ rings, respectively. After the aphids were placed in the cages, the under side of the ring was covered with a net. Usually, the aphids were allowed to feed after having been starved for $3 \mathrm{hr}$. All feeding was carried out under lights in a room regulated at $20 \mathrm{C}$. The infectivity assay of the acquired TMV or TMV-RNA was made as follows; one or more aphids, together with a drop (10-20 microliters) of bentonite suspension containing a small amount of Carborundum, were fully homogenized on a slide glass by watchmaker's forcep. The homogenate was inoculated to a leaf of $N$. glutinosa by rubbing it directly with the slide glass. Immediately after inoculation, each leaf was rinsed with tap water. The bentonite suspension was prepared by the procedure of Fraenkel-Conrat et al.5), and suspended in $0.1 \mathrm{M}$ phosphate buffer, $\mathrm{pH} 7.0$, containing $0.02 \mathrm{M}$ sodium oxalate at a concentration of $23 \mathrm{mg} / \mathrm{ml}$. The oxalate was found to cause the increase of TMV and TMV-RNA infections on $N$. glutinosa ${ }^{23}$. Young plants of $N$. glutinosa having 5-7 leaves were chosen for inoculation with homogenates. Extreme care was taken to prevent contamination by extraneous TMV in these experiments. All glassware, cages, and the inoculating forceps were sterized before use.

\section{Results}

\section{Application of bentonite for assaying the infectivity of TMV and TMV-RNA acquired by aphids}

Aphids were allowed to feed on purified TMV at concentrations ranging from 0.001 to $10 \mathrm{mg} / \mathrm{ml}$ through a membrane for $24 \mathrm{hr}$. Each of these aphids was then homogenized, together with the bentonite suspension, and inoculated to $N$. glutinosa. The results are shown in Table 1. The acquisition of the virus by aphids which had fed on 1 or $10 \mathrm{mg} / \mathrm{ml}$ TMV was easily detected by inoculation with bentonite. The infectivities recovered from the aphids increased with increases in the concentration of TMV which had been presented to aphids. In another experiment, aphids which had been allowed to acquire TMV were homogenized with bentonite suspension in groups of either 5,10 , or 20 and inoculated to 2 or 3 leaves of $N$. glutinosa. The infectivity recovered increased with the number of homegenized aphids.

A further experiment was designated to determine the acquisition period for a single aphid. Aphids were allowed to feed on purified TMV at $10 \mathrm{mg} / \mathrm{ml}$ for 1 minute to $43 \mathrm{hr}$.

\footnotetext{
* Made by American Can Company
} 
Table 1. Infectivity of TMV acquired by aphids from purified TMV through membrane

\begin{tabular}{crr}
\hline $\begin{array}{l}\text { Concentration of TMV } \\
\text { presented to aphids }(\mathrm{mg} / \mathrm{ml})\end{array}$ & $\begin{array}{c}\% \text { of aphids which acquired } \\
\text { TMV }^{\text {a) }}\end{array}$ & $\begin{array}{c}\text { Average number of local } \\
\text { lesions per aphid }\end{array}$ \\
\hline 0.001 & $0 / 40=0.0$ & $0 / 40=0.0$ \\
0.01 & $5 / 49=10.2$ & $6 / 5=1.2$ \\
0.1 & $38 / 81=44.4$ & $183 / 36=5.1$ \\
1.0 & $33 / 45=73.3$ & $407 / 33=12.3$ \\
10.0 & $69 / 71=97.9$ & $4093 / 69=59.3$ \\
\hline $10.0^{\text {c) }}$ & $2 / 5=40.0$ & $3 / 2=1.5$ \\
\hline
\end{tabular}

a) Number of aphids which acquired TMV/total number of aphids tested individually.

b) Total number of lesions produced on $N$. glutinosa/number of aphids which acquired TMV.

c) Bentonite was not used when aphid homogenates were inoculated.

Each aphid was then homogenized with the bentonite suspension and inoculated to $N$. glutinosa. The first recovery of TMV was obtained in one out of 14 aphids which had fed on the purified TMV for $6 \mathrm{~min}$. The subsequent recovery of TMV increased with increase in feeding period. The feeding period required for recovering infectious TMV from more than $90 \%$ of the aphids tested, was $12 \mathrm{hr}$ or more.

To detect infectious TMV-RNA which had acquired by aphids, TMV-RNA at a concentration of $1 \mathrm{mg} / \mathrm{ml}$ in the presence of $15 \%$ sucrose was fed to aphids for 1 or 2 days in the same manner as the above experiments. The aphids, in groups of either $1,5,10$, or 20 were homogenized with bentonite suspension and inoculated to $N$. glutinosa. No infectivity was obtained from the aphids in repeated experiments.

Aphids were reared on tobacco (N. tabacum L. cv. White Burley, and cv. Samsun) or tomato plants infected with $\mathrm{O}$-strain or L-strain of TMV, and on turnip plants infected with C-strain of TMV. After having been reared on the infected plants for several days, each of the aphids was examined for infectivity by the bentonite method. The results are shown in Table 2. Infectious TMV was recovered from these aphids reared on infected plants, but the recovery was less than those from purified TMV at 0.1 or $1.0 \mathrm{mg} / \mathrm{ml}$. The infectivity of TMV from aphids fed on tomato were greater than those in aphids which fed on infected tobacco or turnip.

Table 2. Infectivity of TMV acquired by aphids from infected plants

\begin{tabular}{lcc}
\hline \multicolumn{1}{c}{ Virus source } & $\begin{array}{c}\% \text { of aphids which } \\
\text { acquired TMV }\end{array}$ & $\begin{array}{c}\text { Average } \\
\text { local lesions } \\
\text { per aphid }\end{array}$ \\
\hline Samsun infected with O-strain of TMV & $13 / 47=27.7$ & $48 / 13=3.7$ \\
White Burley infected with O-strain of TMV & $7 / 32=21.9$ & $51 / 7=7.3$ \\
Tomato infected with O-strain of TMV & $19 / 29=65.5$ & $105 / 19=5.6$ \\
Tomato infected with L-strain of TMV & $18 / 40=45.0$ & $92 / 18=5.1$ \\
Turnip infected with C-strain & $17 / 80=21.0$ & $95 / 18=5.6$
\end{tabular}

a) Number of aphids which acquired TMV/total number of aphids tested individually.

b) Total number of lesions produced on $N$. glutinosa/number of aphids which acquired TMV.

\section{Retention of infectious TMV by aphids}

After aphids were fed on purified TMV at $10 \mathrm{mg} / \mathrm{ml}$ for $24 \mathrm{hr}$ through a membrane, 
Table 3. Retention of infectious TMV by aphids which acquired purified TMV

\begin{tabular}{ccc}
\hline $\begin{array}{c}\text { Days after } \\
\text { acquisition } \\
\text { of TMV }\end{array}$ & $\begin{array}{c}\% \text { of aphids which } \\
\text { acquired TMVa) }\end{array}$ & $\begin{array}{c}\text { Average number } \\
\text { of local lesions } \\
\text { per aphid }\end{array}$ \\
\hline 0 & $30 / 30=100.0$ & $2076 / 30=69.2$ \\
1 & $30 / 30=100.0$ & $1380 / 30=46.0$ \\
2 & $34 / 45=75.6$ & $405 / 34=11.9$ \\
3 & $6 / 45=13.3$ & $24 / 6=4.0$ \\
4 & $0 / 30=0.0$ & $0 / 0=0.0$ \\
\hline
\end{tabular}

a) Number of aphids which acquired TMV/total number of aphids tested individually.

b) Total number of lesions produced on $N$. glutinosa/ number of aphids which acquired TMV.

Table 4. Infectivity of honeydew released by aphids which had acquired TMV through membrane ${ }^{a)}$

\begin{tabular}{cc}
\hline $\begin{array}{c}\text { Days after acquisition } \\
\text { of TMV }\end{array}$ & $\begin{array}{c}\text { Number of local } \\
\text { lesions }^{\mathrm{b}} \text { ( }\end{array}$ \\
\hline 1 & 641 \\
2 & 159 \\
3 & 43 \\
4 & 18
\end{tabular}

a) The honeydew was prepared from five groups of fifty aphids which acquired TMV

b) These figures show total number of lesions pro. duced on 10 to 12 leaves of $N$. glutinosa. they were transferred to other cages covered with membranes containing $15 \%$ sucrose in $0.02 \mathrm{M}$ phosphate buffer. After a given period, the infectivity of homogenized aphids was determined by the same procedure as in above experiments. It was found that infectious TMV in aphids which had acquired TMV decreased with days after acquisition of TMV. The aphids which had acquired TMV lost most of the infectious TMV after 2 or 3 days, though it varied with the individual case. No TMV could be detected in aphids after 4 days of feeding on the sucrose solution. The results are shown in Table 3.

\section{Release of infectious TMV by stylet of aphids}

To determine whether infectious TMV could be released by stylet of aphids which had acquired TMV into $15 \%$ sucrose in $0.02 \mathrm{M}$ phosphate buffer, aphids which were allowed to feed on purified TMV at $10 \mathrm{mg} / \mathrm{ml}$ for $24 \mathrm{hr}$, were transferred to cages containing $0.7 \mathrm{ml}$ sucrose solution covered with membranes. After letting the aphids feed for 1 to 3 days, the sucrose solution was collected and inoculated to $N$. glutinosa together with bentonite suspension. No infection occurred with these sucrose solutions in 3 experiments, each using 180 aphids which had acquired TMV. Further, no infectious TMV was found in the extracts of each disk of $N$. glutinosa. turnip, tomato, tobacco, and Rumex obtusifolius L. when they were fed by 100 aphids which had acquired TMV.

\section{The infectivity in honeydew of aphids which had acquired TMV}

An experiment was performed to determine whether infectious TMV could be recovered from the honeydew of aphids acquired TMV. Feeding cages with the membranes containing $15 \%$ sucrose in $0.02 \mathrm{M}$ phosphate buffer were prepared for obtaining the honeydew. Groups of 50 aphids which had acquired TMV were placed in each cage and then the cages were screened with gauze. To obtain the honeydew produced at one day intervals, the aphids were transferred to new cage at one day intervals. After removal of the aphids and sucrose solution, the inside of the cage was repeatedly wiped with the gauze used for screen, to which a bentonite supsension of $0.3 \mathrm{ml}$ and a small amount of Carborundum was added. The infectivity of individual cages was also determined by inoculating on 2 or 3 leaves of $N$. glutinosa with the gauze. The total number of local lesions produced on 10 or 12 leaves from 5 cages are shown in Table 4. It is obvious that the majority of TMV acquired by 
aphids was released in the honeydew after 1 or 2 days. The results here agree with those of the retention of TMV by aphids as shown in Table 3.

\section{The inactivation of TMV by aphids}

A further experiment was performed to test the inactivation of TMV acquired by aphids. Aphids fed on purified TMV of $\mathrm{O}$ - and $\mathrm{C}$-strain at $10 \mathrm{mg} / \mathrm{ml}$ through a membrane for $24 \mathrm{hr}$ were killed by placing in a freezer ( $-15 \mathrm{C}$ ) over night. The dead aphids were individually placed on slide glasses with a drop of water. The aphids were maintained at room temperature for a given period. Each of these aphids was homogenized, together with bentonite suspension, and inoculated to $N$. glutinosa. The average number of local lesions produced on a leaf of $N$. glutinosa are shown in Table 5. The infectivity recovered from dead aphids decreased with increasing incubation periods at room temperature. The decrease in the infectivity of $\mathrm{C}$-strain was greater than those of $\mathrm{O}$-strain. The results indicate that TMV acquired by aphids was inactivated by some factor within the aphids. In this experiment, it was also found that the recovery of infectivity from aphids which had acquired TMV was promoted by the freezing procedure of the aphids, as compared to other experiments mentioned above.

\section{Discussion}

Takahashi and Orlob ${ }^{22)}$ stated that infectious TMV could be recovered from the dissected ventriculus and honeydew of aphids which had been fed on purified TMV. In comparing the results using bentonite to those of Takahashi and Orlob, it is obvious that bentonite shows a strong counteracting effect on the inhibitory activity in the insect homogenates, so that infectious TMV can be detected in a single aphid. Detection of infectivity of TMV-RNA acquired by aphids, was unsuccessful. It may be caused by inactivation in an aphid, because it was easily inactivated by a small amount of aphid homogenate, and is known to be inactivated by ribonuclease and the other inhibitors ${ }^{24}$. The application of bentonite seems to be effective in detecting infectious TMV in other insects, too. In my preliminary studies infectivity of TMV was detected by using bentonite in the homogenates of butterflies or the other insects which had been fed on infected plants or purified TMV (unpublished data). The amount of TMV acquired by aphids from infected plants was smaller than that from purified TMV, though the extracts of the infected plants were highly infectious. On the contrary, infectious TMV was not released by the stylet of aphids which had acquired TMV. Pirone ${ }^{14)}$ initially demonstrated that aphids acquired TMV can release infectious TMV when allowed to probe buffer solution and used local lesion tobacco for assay. The failure of detection of infectious TMV in release by the stylet may be caused by the lower sensitivity of $N$. glutinosa to TMV infection, or the methods used in the present experiments. 
On the basis of the results obtained, it is considered that infectious TMV imbibed by aphid can not be released by the stylet, whereas it is released in the honeydew after short period of feeding. Takahashi and Orlob ${ }^{22}$ stated that TMV particles were not seen in the hemolymph of aphids acquired TMV, and that infectivity of TMV reduced when injected in the hemolymph of aphids. Similar inactivation of TMV in dead aphids was observed in the present experiments as shown in Table 5. The precise mechanism of the inactivation of TMV is unknown, but further experiments in this respect are in progress at the present time.

I thank Professor Thomas P. Pirone and Professor E. Shikata for reading my manuscript and their valuable suggestions.

\section{Literature cited}

1. Black, L. (1939). Phytopathology 29 : 321-327.

2. Brownhill. T. J., Jones, A. S. and Stanley, M. (1959). Biochem. J. 73 : 434-438.

3. Cornuet, P. and Morand, J. D. (1960). C. R. Acad. Sci. 250: 1583-1584.

4. Cornuet, P. and Morand, J. D. (1960). Ibid. $250: 1750-1752$.

5. Fraenkel-Conrat, H., Singer, B. and Tsugita, T. (1961). Virology $14:$ 54-58.

6. Fukushi, T. (1930). J. Sapporo Soc. Agr. Forest. $22:$ 305-320.

7. Hoggan, Ismé A. (1931). Phytopathology 21: 199-212.

8. Hoggan, Ismé A. (1934). J. Agr. Res. 49: 1135-1142.

9. Kennedy, J.S., Day, M.F. and Eastop, V. F. (1962). A Conspectus of Aphids as Vectors of Plants Viruses. Commonwealth Inst., London.

10. Kikumoto, T. and Matsui, C. (1962). Virology $16: 509-510$.

11. Matsui, C., Sasaki, T. and Kikumoto, T. (1963). Ibid. 19: 411-412.

12. Nishi, Y. (1958). Ann. Phytopath. Soc. Japan 23 : 185-188.

13. Orlob, G. B. (1963). Phytopathology 53: 822-830.

14. Oshima, N., Goto, T. and Sato, R. (1960). Bull. of Hokkaido Nat. Agr. Exp. Sta. 78: 74-80.

15. Oshima, N., Goto, T. and Sato, R. (1964). Ibid. $83: 87-99$.

16. Ossiannilsson, F. (1958). Kgl. Lantbrukshogsk. Ann. 24 : 369-374.

17. Pirone, T. P. (1967). Virology 31: 569-571.

18. Singer, B. and Fraenkel-Conrat, H. (1961). Ibid. 14: 59-65.

19. Smith, K. M. (1965). Adv. Virus Res. 11: 61-96.

20. Steere, R. L. (1959). Ibid. 6: 1-73.

21. Takahashi, W. N. (1951). Phytopathology $41: 142-145$.

22. Takahashi, Y. and Orlob, G.B. (1972). Ibid. 62:429-433.

23. Yoshizaki, T. (1976). J. Hokkaido Univ. of Education $26: 5-15$.

24. Yoshizaki, T. (1980). Ibid. 30: 57-85. 
和 文 摘 要

\author{
ベントナイトの使用による単一アブラムシ中の感染性 TMV の検出 \\ 由 崎 俊 道
}

タバコモザイクウイルス (TMV) に感染した植物あるいは純化TMV を膜ごしに与えたアブラムシにベン トナイト愁濁液を加えて磨砕し, Nicotiana glutinosa L.に接種することによって，一頭のフブラムシ体内の 感染性 TMV を検出することができた。TMV-RNA を与えたアブラムシから，この方法によって感染性の ある TMV-RNA を検出することはできなかった。TMV を獲得させたフブラムシを15\%の萑糖を含さ0.02 Mの燐酸㖃衝液を膜ごしに吸汁させて飼育した場合には，アブラムシ体内の感染性 TMVは 3 あるいは4 日 後に認められなくなった。アブラムシ体内の感染性 TMV の大部分は honeydew 中に放出されるが，口針 から庶糖液あるいは植物の disk へは放出されなかった。死んだフブラムシ体内の TMV 活性は, それらの フブラムシを室温に保つことによって徐々に減退した。このことはアブラムシ体内において TMVが不活性 化されるむのと考えられる。 